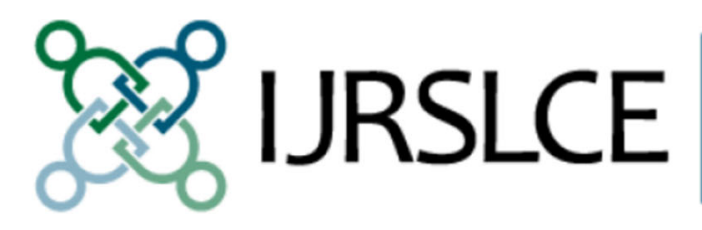

International Journal

for Research on

Service-Learning \&

Community Engagement

\title{
The Emerging 360 Degree Model for Global Citizenship Education
}

\author{
Karen R. Breitkeurz \\ Tony D. Songer
}

This article was originally published at:

https://journals.sfu.ca/iarslce/index.php/journal/article/view/121/76

Recommended Citation

Breitkreuz, K. R., \& Songer, T. D. (2015). The emerging 360 degree model for global citizenship education. International Journal of Research on Service-Learning and Community Engagement, 3(1), Article 4. 


\title{
The Emerging 360 Degree Model for Global Citizenship Education
}

\author{
Karen R. Breitkreuz \\ Tony D. Songer \\ Boise State University
}

\begin{abstract}
Collaborative efforts in the health sciences and STEM fields offer tremendous opportunities for providing solutions to the global challenges of reducing poverty and improving health care. Global health care challenges necessitate the investigation of new interdisciplinary educational approaches for higher education. This article presents a formal approach for developing students into well-equipped global citizens, through the Emerging 360 Degree Model for Educating Socially Responsible Global Citizens. This model provides a framework for creating educational environments and academic coursework that promotes global citizenship education. Students' knowledge, comprehension, and skills are addressed through in-class discussion and experiential international service-learning in a "village network" setting. Post-trip reflection and presentations embedded in the model encourage students to explore deeper layers of meaning, and leadership and team influences propel students to engage as socially responsible global citizens. This article describes the Emerging 360 Degree Global Education Model and reports on initial findings of the impact of the educational approach on student learning. Qualitative and quantitative data from student surveys and reflective essays offer information on students' growth in global citizenship understandings.
\end{abstract}

Keywords: service-learning, service-learning model, international service learning

Health is not only to be well, but to use well, every power we have.

-Florence Nightingale, 1893

Public and private organizations continue to emphasize the importance and broad impacts of globalization. Global competitiveness and interdependence, resulting from an increasingly interconnected global society and economy, create an imperative for graduates of U.S. colleges and universities to become globally competent and socially responsible citizens (Bringle, Hatcher, \& Jones, 2011; Partnership for 21st Century Skills, 2012; Pelligrino, 2012; United Nations, 2014). Yet disparity among global populations is great, and problems of poverty, hunger, and disease plague the majority. Without healthy societies, competitiveness will remain an option for only the elite.

The global nature of our increasingly "flat world" (Friedman, 2007) requires next generation (NextGen) professionals to become global citizens. However, many U.S. higher education models do not provide effective programs for students to contemplate their responsibilities as global citizens. Despite university efforts to achieve internationalization goals through study-abroad programs and other internationalization initiatives, such efforts often lack rigor or an ability to systematically measure outcomes. Furthermore, professional education programs in the fields that may hold many of the solutions 
to pressing global problems (e.g., health sciences, bio and geo-sciences, and science, technology, engineering, and math [STEM] fields) have curricular schedules that are too intensive to allow students time to study abroad if they hope to finish their respective program of study in the typical four years.

This article presents the Emerging 360 Degree Model for Global Citizenship Education (or the Emerging 360 Degree Global Ed Model, for short) as a solution for educators who hope to develop theoretically sound study-abroad programs benefitting not only U.S. students but also international community partners. The model, developed by the authors, is appropriate for undergraduate and graduate students in both health-science and STEM disciplines and is delivered through instructor-led coursework. This article describes the model as well as initial findings from a preliminary retrospective pilot study that demonstrated student growth in global understandings and intercultural abilities, and generated themes from students' reflections on this academic service-learning experience. Conclusions focus on the educational imperatives for global citizenship education and the unique approach this model offers for health-science and STEM professionals.

\section{Background}

Health-science and STEM disciplines provide the foundation for solving many of the worlds' pressing issues (Business Roundtable, 2008; Sununu, 2013). In fact, when partnered, the health-science and STEM communities may offer the strongest solutions for creating healthy societies and addressing problems of poverty and inequity. This collaboration, however, necessitates the preparation of future leaders who possess the ability to work in creative, innovative, interdisciplinary environments and who are globally sophisticated and culturally aware (ABET, 2014; Duderstatt, 2008; Harvan, 2009; National Academy of Engineers, 2004). The imperatives for intentional global citizenship education and interdisciplinary collaboration, along with the need for models and student pulls, frame the basis for our model.

\section{Educational Imperatives for Global Citizenship}

Global citizenship is a concept that includes a set of guiding principles by which one relates to and experiences the wider global landscape in respectful, sustainable ways (Oxfam Development Education Programme, 2006). Schattle (2008) defined global citizenship by describing the practices of global citizens, who "demonstrate awareness" of the larger global landscape, "take responsibility," and "participate in community solutions." The American Council on Education (ACE) (as cited in Bringle, Hatcher, \& Jones, 2011) recommended that students should acquire the knowledge, skills, and attitudes of global citizens through a variety of international experiences that enable them to understand world cultures and events, appreciate cultural differences, analyze global systems, and apply this knowledge to their lives as citizens and workers. Hunter (2004) emphasized the need for competent performance in global professionals, defining global competence as having an open mind while actively seeking to understand cultural norms and expectations of others, then leveraging this gained knowledge to interact, communicate, and work effectively outside one's home environment. All of these concepts are essential to designing curriculum through which students can grow and student outcomes can be measured. International service-learning professionals agree, yet research to date is limited.

\section{The Need for Integration in Health-Science and STEM Education}

Recent calls to reform health-science and STEM (science, technology, engineering, and math) education place strong emphasis on applying the sciences within the broader context of globalization, economics, the environment, and society. The Institute of Medicine's (2003) report Unequal Treatment: Confronting Racial and Ethnic Disparities in Health Care stated that we must "integrate cross-cultural education into the training of all current and future health professionals" ("Recommendation 6-1"). Similarly, Currier (2009) held that globally competent health-care providers should maintain a holistic perspective of the health beliefs and practices of other cultures, as well as an awareness of complex cultural, social, political and economic interrelationships within and between nations. Recent outbreaks of the Ebola virus in West 
Africa, compounded by the complexities of containing the virus at the place of origin and by subsequent transmission to the U.S., offer glimpses into the urgency of these issues.

The National Academy of Engineering's report, The Engineer of 2020, called for fundamental change in the structure, policies, and practices of engineering education (NAE, 2004). The report urged engineers to recognize what they can build for the future through a wide range of leadership roles in industry, government, and academia, not just through technical jobs but also in global leadership roles. The NAE believes that a paradigm shift, from a focus on technical education to industry leadership, will enable engineers to meet the demands of globalization, and that technology-based concerns must be balanced with socially oriented demands (Kuhn, 1998). Conway (2000) stated that elements of good design practice must include the ability to define a problem through responsible judgments based on wide consultation, sensitivity to social, cultural, and moral issues, acknowledgment of the political and economic context, and critical reflection including consideration of realistic economic, environmental, social, political, ethical, health and safety, manufacturability, and sustainability constraints. Leaders from STEM and health-science disciplines have voiced a clear imperative to integrate key global citizenship concepts into undergraduate education.

\section{Need for Formal Models}

Hudzik (2011) posited that internationalization can ultimately leverage the collective assets of the higher education sector to create a new generation of global citizens capable of advancing social and economic development for all. In their current efforts to internationalize campuses, colleges and universities recruit foreign students and send over 200,000 U.S. students per year to study abroad (Bass, 1998). However, student exchange and study-abroad programs vary greatly, and the extent to which they prepare or challenge students to collaborate with one another and/or bring meaningful solutions to global problems is difficult to measure.

According to Helms (2012), global engagement is about committing to meaningful relationships with partners in other parts of the world. Green (2013) challenged colleges and universities to implement global citizenship practices on a deeper level by ensuring that efforts are mutually beneficial and enhance the well-being of partner communities. International service-learning organizations, such as the International Partnership for Service-Learning (IPSL), offer opportunities to students who want to undertake service in their field and can afford to spend a semester or a year abroad. Their programs provide useful reflection experiences through which students can enhance their global citizenship understandings. However, while these programs describe outcomes that include increased intercultural sensitivities and global understanding, it remains unclear if students are able to apply (or even utilize) professional job skills appropriately in these service experiences. Furthermore, we were unable to find any programs that offered interdisciplinary service-learning options for health-science and STEM majors. Indeed, through a thorough review of the literature from 2013 to 2015, we did not find any education models that demonstrated effective methods for educating and retaining health-science and/or STEM majors by improving globally necessary workforce skills.

\section{Research on Study Abroad to Date}

Research on study abroad supports the importance of immersion experiences in enhancing student outcomes in intercultural awareness and sensitivity, and it demonstrates the many benefits of study-abroad experiences. In 2010, Sutton and Rubin released the final research outcomes from a major 10-year, multi-site study referred to as the Georgia Learning Outcomes of Students Studying Abroad Research Initiative (GLOSSARI). The GLOSSARI study effectively demonstrated different outcomes for study-abroad and traditional non-study-abroad students. Their research documented study-abroad student growth in intercultural sensitivity, cultural navigation skills, personal growth, and many other cultural skills that surpassed such skill growth among students who studied cross-cultural concepts only in a U.S. classroom. The study also demonstrated improved graduation rates for study-abroad students compared to non-study-abroad students in the range of $10 \%$ to $30 \%$, depending on strata reviewed (Sutton \& Rubin, 
2010). Unfortunately, research on the effectiveness of international studies in STEM and/or health-science majors is virtually nonexistent (Mbugua, 2010).

\section{Student Pulls}

The final impetus for the Emerging 360 Degree Global Ed Model relates to students themselves. Educators are constantly being challenged to create learning environments that are relevant to new generations of college students, such as the current "millennials" and members of "Generation Z." The millennials, born between 1980 and 2000, comprise the largest and most diverse generation ever to enter college (Strauss, 1991). Generation Z (or Gen Z) includes those who were born between the mid- to late-1990s and the present, and who are just now entering college (Looper, 2014). Generally, millennials are team-oriented, confident, respectful, civic-minded, pressured, achievement-oriented, and conventional. They enjoy collaborative, cooperative, social learning, and want educational content linked to real-life problems (Martin, 2007). These students engage in problem solving by integrating sociological situations from a variety of cultures (Kolb, 1984) and feel that "doing is more important that knowing" (Northern Illinois University, 2011). Generation Z (or Google generation) students tend to be tech savvy and accepting of diverse populations because they have been globally connected since birth (Renfro, 2012). These students must be taught to discover, curate, manage, and think critically about all of the information they must process (Renfro, 2012). Renfro (2012) suggested that once connected, members of Gen $\mathrm{Z}$ will collaborate with peers across the globe. The current global landscape combined with millennial and Gen $Z$ learner characteristics have converged to necessitate the provision of flexible, meaningful learning environments in which these students can connect with and solve problems both locally and globally (Jonas-Dwyer \& Pospisil, 2004).

\section{The Emerging 360 Degree Global Ed Model}

We propose a service-learning method that provides learners with a progressive, interdisciplinary curriculum that in turn allows real-world problem solving in an authentic global context. Student transformation takes places as learners make sense of the global context, create relationships with village partners, and observe global citizenship characteristics in their faculty. Professional skills are refined as students develop and create solutions through projects that meet partners' needs. Students share their knowledge with each other, while expanding their professional repertoire. Ultimately, they return home to reflect on the meaning of the service-learning experience and expand their understandings and attitudes of and toward global citizenship. This is the Emerging 360 Degree Global Ed Model.

\section{Concepts Integral to the Emerging 360 Degree Global Ed Model}

The notion of global citizenship is integrated from several research efforts and includes the concepts of global citizenship, intercultural competence, and global competence.

Schattle's (2008) essential practices of global citizenship include awareness, taking responsibility, and participation. Schattle suggested that awareness should include both an awareness of oneself, as suggested by Deardorff (2006), and the outside world, as well as an awareness of global interdependence and interconnectedness. The second characteristic of global citizenship involves taking responsibility. Those who are responsible understand that local loyalties do not justify forgetting that each human being has responsibilities to others within the large landscape. Finally, Schattle (2008) maintained that global citizens should participate in the affairs of the community and actually influence the people who they are exposed to by doing and saying what they know is good and right. They choose to have a voice within communities at home and abroad. This expanding-horizons concept of global citizenship emphasizes increasing and intensifying relationships between individuals and communities.

Intercultural competence centers on relating to another culture in a competent manner. Deardorff (2006) suggested that in order to be culturally competent, one must have specific knowledge, skills, and attitudes, including maintaining openness to others and other cultures, withholding judgment, respecting 
and valuing others, fostering curiosity and discovery, and tolerating ambiguity. Learners build on these attitudes by gaining knowledge of cultures, customs, beliefs, and languages, and by becoming culturally self-aware (Deardorff, 2006). Culturally competent individuals are also able to listen, observe, evaluate, analyze, interpret, and, finally, relate to others in a new culture (Deardorff, 2006; Littleton, McMahon, \&Wigal, 2008; Ruddock \& Turner, 2007).

Hunter (2004) defined global competence as "having an open mind while actively seeking to understand cultural norms and expectations of others, and leveraging this gained knowledge to interact, communicate and work effectively in diverse environments" ("Definition of Global Competence"). Hunter's (2014) Global Competence Aptitude Assessment is a systematic method for evaluating these competencies. International businesses currently utilize this instrument to determine employee readiness for global assignments. Student versions of the assessment are available for educators.

Preparing NextGen leaders includes integrating these globalization concepts into the undergraduate curriculum and increasing the awareness and skills of students in all areas of global competence and citizenship. Within the context of STEM and health-science education, global competencies must include sensitivities to the social, cultural, political, ethical, and moral impacts of science, technology, and health-science and/or engineering-based global solutions (Conway, 2000; Currier, 2009; MBugua, 2010).

The Emerging 360 Degree Global Ed Model brings together a variety of educational concepts to form a unified educational approach that impacts students' knowledge, attitudes, and personal and professional skills through partnerships with an international community. Pilot study findings have demonstrated the model's potential for educating socially responsible global citizens.

\section{Development of the Model}

In 2012, we began an interdisciplinary collaboration by partnering with Peacework, a nongovernmental organization that connects educators and universities with village partners in areas of the world where such partnerships can be mutually beneficial. The result of this initial partnership was the development of the Emerging 360 Degree Global Ed Model (see Figure 1).

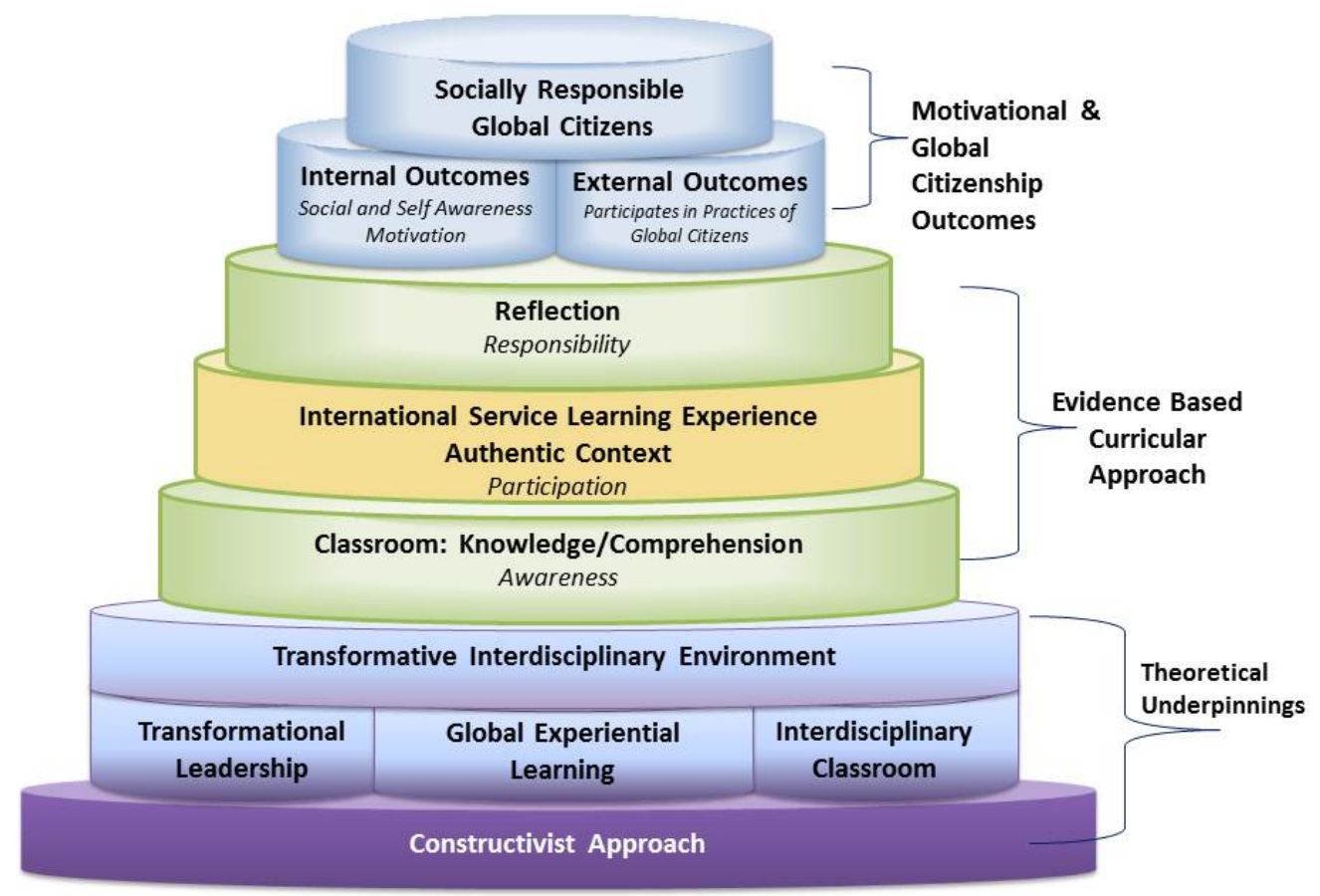

Figure 1. Emerging 360 Degree Model for Global Citizenship Education. 
The model demonstrates the theoretical basis of our classroom approach, the foundational elements of the program, the evidence-based curricular orientation, and the intention to create both internal and external outcomes in learners. Internal outcomes include the motivations that propel a person to engage in practices of global citizenship, while external outcomes comprise the knowledge and skills (technical and personal) that can be improved continuously as one engages in knowing and furthering his or her involvement in global issues (Deardorff, 2006). The transformative interdisciplinary learning environment embodies the constructivist-based theories of transformational leadership, experiential learning, and interdisciplinary teaming (explained in later sections).

\section{Becoming global citizens.}

We suggest that the process of becoming a global citizen requires a reordering of Schattle's model to first of all gaining awareness, then participating (with guidance) in a global village, and finally taking responsibility. This is operationalized in the education setting through a guided international service-learning experience. Awareness begins during pre-trip classroom discussions, during which faculty members introduce concepts of global competence, global citizenship, and social responsibility, and that awareness continues to grow throughout the immersive in-country experience. Service-learning begins when students sign-up to help implement solutions to problems identified by the village network partners. Interdisciplinary teams must define a project scope, outline a solution, and identify appropriate local (i.e., onsite) resources for project implementation. Students form teams and take turns leading and learning from other classmates with expertise in other disciplines. The teams develop and construct solutions for health- and STEM-based community problems identified previously by international partners. Participation begins at home but expands through an immersive in-country service-learning experience, which authenticates and challenges student perceptions. Students must form relationships with community partners and gain approval prior to implementing any ideas. The experience provides an opportunity for personal growth, leadership, and teamwork. It reinforces project planning and discipline-specific knowledge and skills. Students must apply their knowledge, budget time and materials, and implement specific projects that range from elementary health education sessions to construction projects. This experience provides a rich contextual learning environment that acts as a catalyst to help students synthesize course concepts and skills. Responsibility develops as students reorganize plans, evaluate daily progress and community impressions, reflect on their experiences, and link those actual experiences to abstract theories and perceptions.

\section{Theoretical Underpinnings}

The theoretical underpinnings for the Emerging 360 Degree Global Ed Model include constructivism, interdisciplinary learning, transformational leadership, and international service-learning. Each of these factors is a necessary component of the model and is briefly reviewed here. In addition, the model clearly demonstrates how students progress through each learning domain, by gaining knowledge, comprehending, and applying and synthesizing their new knowledge and skills in the village setting. Furthermore, students are challenged to apply their professional knowledge and team-building skills by designing actual solutions to stated community needs. When the students return home, they are able to evaluate and reflect on all aspects of their experience, deepening their understandings.

Constructivism. Constructivism is a core educational theory based on the premise that perspectives are constructed through one's individual experiences. The ability to solve problems and take responsibility for learning ultimately resides in the learner; in making meaning of their educational experiences, learners grow and expand their intellectual, social, and global horizons (Harvan, 2009).

Interdisciplinary learning. In the context of the model, interdisciplinary learning takes places as students from every discipline in the university are invited to participate and as they share their expertise in groups during project development. In an inter-professional environment, learners build cooperative, collaborative, and social learning skills. They are challenged to develop inter-professional knowledge of team and leadership competencies. This team- and trust-building begins prior to the field experience through the articulation of a shared vision and by participating in collaborative assignments. However, as 
the experiences unfold in the field, the team members often build a great deal of skill in adapting to new and challenging situations, resolving conflict, and adjusting to the ever-present need for flexibility. The inter-professional social environment then provides a safe space in which students can understand the significance and importance of their own professional discipline and the contribution, importance, and connectedness of the contributions of those from other disciplines (Harvan, 2009). Interdisciplinary education creates a "T-student," one who has both breadth and depth in his or her ability to process a great deal of information and to apply new skills while serving a larger social good (Bergland, 2010; Posnick-Goodwin, 2010).

Transformational leaders. Transformational leaders are role models who inspire others, demonstrate consideration, promote intelligent stimulation, and foster acceptance of group goals. Traditional education models often feature the professor as the expert - the "sage on a stage." However, in today's society where information is instantly accessible and quickly outdated, students value doing more than knowing (Northern Illinois University, 2011). In fact, millennial students display frustration when faculty try to leverage personal expertise. Transformational leaders, instead, inspire students to achieve extraordinary outcomes by solving real-world problems. They encourage learners to develop and create solutions to problems, create relationships with international partners, and develop their own leadership capacities. Transformational leaders also help learners to grow by responding to their individual needs and by encouraging them to align their personal objectives and goals with the needs of the community and with the group's educational goals (Bass, 1998). Correlations between transformational leaders' teaching behaviors and millennial students' needs are well documented (Mawn, Callow, Hardy, \& Arthur, 2011).

International service-learning. International service-learning is essential to the effectiveness of the Emerging $360^{\circ}$ Global Ed Model. Service-learning is grounded in experiential education theory (Dewey, 1938; Kolb, 1984; Piaget, 1952), which holds that experience is the foundation of learning and that service, in a variety of forms, provides an authentic context. As students apply the knowledge they have acquired they are tasked with developing meaningful solutions to real world problems, and they are immersed in an environment that provides a rich societal context for personal and professional growth. Furthermore, the development of global citizenship and competence requires reflection on the immersive, international experience (Astin, Vogelgesan, Ikeda, \& Yee, 2000). Research by Ruddock and Turner (2007) suggested that the development of cultural sensitivity (among students studying abroad) occurs in a circular process in which students experience stress in a strange environment, take on the ways of the host culture, and compare the host culture with one's own. The rich, contextually based global service-learning experiences evident in the model are followed by guided reflection that subsequently provides a transformative environment for student learning (Dewey, 1938; Ruddock \& Turner;). The benefits of these service-learning experiences include positive impacts on students' analytical and critical thinking and interpersonal skills, and improved engagement and professional commitment.

International partnerships. International partnerships are the final link in the Emerging $360^{\circ}$ Global Ed Model. International service partners from Peacework assist university faculty in connecting with village partners. This collaboration, approved by university administrators and host-country authorities, connects students and faculty with a local village that invites collaboration. This collaboration then provides a multi-disciplinary, collaborative, international service-learning experience to students for a portion of the semester.

As students participate in the class, they gain knowledge, insight, and ultimately experience as global citizens. Multi-disciplinary student teams from health science, education, engineering, and other disciplines have developed integrated solutions for village communities and schools which have been requested by village partners. To date, these solutions have included the development of an educational curriculum for local school children in a Healthy Lifestyle Day-Camp and the completion of construction projects such as playground upgrades, school-garden renovation, a chicken-coop, and a cantina for school lunch programs.

\section{The International Experience}

Upon arriving at the partnering village (currently over an extended spring break), students meet with 
network partner leaders (teachers, principals, and other community partners) to finalize their project plans. These plans must include a detailed list of the materials required, quantities and cost estimates, a project schedule, a resource utilization plan, and a daily safety plan. Building design considerations include the use of local materials, ease of use, and sustainability, as well as operations and maintenance. Curriculum projects designed by students must be aligned with village and host-country national curricula and be developmentally appropriate for children pre-K to sixth grade.

Once the in-country experience begins, students procure materials locally and offer a morning Healthy Lifestyles Camp on school grounds and complete building projects in the afternoons. Team leadership responsibilities rotate among students. Camp teaching teams have a themed classroom that rotates between school classrooms with age-appropriate lesson plans. Student teams have led literacy classes, healthy lifestyles classes, physical education classes, garden classes, and art classes. Construction projects to date (2008-2014) have included building a water distribution and rainwater harvesting system, trash collection receptacles, school ground paths, several kinder playgrounds, and a chicken coup, and re-establishing a school garden. These projects allow students to work closely with community leaders, teachers, and students of host-country schools, thus fostering long-term global relationships.

Student reflections and presentations complete the course component of the Emerging $360^{\circ}$ Global Ed Model. In writing post-trip reports, students are asked to reflect on how they can participate and take responsibility as global citizens. It is through this post-trip reflection that learners have an opportunity to synthesize new understandings and experiential meanings. In addition, a multi-dimensional final course assessment is used to determine if the approach was successful in terms of student education, growth, and community interaction.

\section{Methods}

After three successive years of coursework in a course entitled Global Citizenship and Social Responsibility-which is cross-listed in the university's health sciences, engineering, honors, and university foundations divisions-IRB approval was obtained to review cross-sectional data from student surveys and reflective essays that were de-identified. Data were obtained from 46 students who had completed the Global Citizenship and Social Responsibility classes, which included 10-day service-learning trips to a small village in the northern region of Belize. Over the course of three years the course included seven males and 39 females. In years two and three, information was collected on participants prior to the international experience $(n=23)$. Three participants reported living abroad for more than six months; 10 had traveled abroad for at least a short time (one week), and five had previous international service-learning experience. Three reported fluency in other languages. One student was foreign born.

To measure self-reported growth in global understanding and cross-cultural skills, a post-assessment scale including 11 Likert-type items was administered. Response ratings ranged from 0 to 6 , with zero meaning "not applicable," 1 signifying no improvement, and 6 signifying great improvement.

In addition to surveys, students were asked to respond to open-ended questions about their experience, such as what new insights they had gained about global citizenship from the course and what they had learned about teamwork. Finally, students' post-service reflections, as recorded in reflective essays, were analyzed.

\section{Findings}

As Table 1 indicates, post-trip assessments demonstrated self-reported growth on all items measuring increases in understanding of global issues and cross-cultural sensitivity. Students reported experiencing the strongest growth in their ability to compare and contrast the host country with their own and in how much they cared about the problems of people in other countries. They reported the lowest gains in their ability to interpret aspects of other cultures. 
Table 1. Self-Assessments of Growth in Global Understandings, Cross Cultural Abilities $(n=44)$

\begin{tabular}{lcc}
\hline Rate your improvement in the following areas: & $\begin{array}{c}\text { 3 year } \\
\text { mean }\end{array}$ & $\begin{array}{c}\text { Standard } \\
\text { Deviation }\end{array}$ \\
\hline Understanding of Global issues & 4.88 & .86 \\
Ability to recognize my own biases, prejudices or stereotypes & 5.07 & .97 \\
Cross-cultural sensitivity & 5.04 & .86 \\
Ability to interpret aspects of other cultures & 4.77 & .81 \\
Ability to compare and contrast my host country with my own & 5.27 & .72 \\
Ability to understand the scope and depth of the health or social problems in the & 4.85 & .90 \\
$\quad$ country I visited & & \\
Ability to relate to people from other cultures & 5.03 & .87 \\
Ability to work with/for people from other cultures & 5.25 & .78 \\
Understanding issues that affect those in the larger global community & 5.26 & .73 \\
Ability to respect others in spite of cultural differences & 5.37 & .78 \\
How much I care about the problems of people in other countries & 5.42 & .83 \\
\hline
\end{tabular}

In year three, data were collected from students regarding their intentions to continue participation as global citizens. Students were asked to rate how likely they would be to continue the practices of global citizenship on a scale of 1 to 5 , using stars as indicators. The more stars, the higher the score. Table 2 shows students' self-ratings on how they planned to continue global citizenship practices.

Table 2. Student Self-Ratings on the Global Citizenship Practices (Post-trip) Scale ( $n=8)$

\begin{tabular}{lcc}
\hline Global Citizenship Practices & Mean & $\begin{array}{c}\text { Standard } \\
\text { Deviation }\end{array}$ \\
\hline I believe I can make a difference in global issues & 3.56 & 1.54 \\
When I interact with a person from a different culture I try to learn as much as I can & 4.25 & 0.93 \\
When I hear news about global events I try to figure out what is really going on & 3.81 & 0.84 \\
$\quad$ & 3.5 & 1.56 \\
$\quad$ I plan to participate in a club or organization that supports or enhances my & 4.25 & 0.88 \\
$\quad$ I will try to find ways to educate others about my cultural experiences & & \\
I will try to keep learning about Global Issues and cultures & 4.63 & 0.74 \\
\hline
\end{tabular}

Student responses to the open-ended items demonstrated positive growth in global learning and cross-cultural skills. A sample of students' responses to the question "What new insights do you have about global citizenship?" are captured in the following quotes:

- I've learned what it means to be a global citizen. Before I could maybe tell you what it vaguely 
sounded like global citizenship should be, now I can tell you that for me, being a global citizen means being there and being open to understanding another culture while working with and learning from the local individuals to improve everyone's overall well-being.

- Global citizenship is more than knowing that I am part of a larger humanity.... Being a socially responsible, global citizen means listening to the perspective of the people and meeting them at their level without assuming that I know better or can do anything better. I am neighbors and friends to the rest of the world and it is my responsibility to open my eyes and heart to that.

- Global citizenship is not something we inherit, but it is a way of thinking that we adopt. It comes to its fullest form when we see others as equals and can appreciate differences in culture ... Global citizenship is shown by our willingness to learn and our efforts to progress as a whole.

In response to the question about what they learned about teamwork from the course, students' answers included:

- You must utilize everyone's strengths to implement powerful projects.

- I learned that working with people from other areas is extremely rewarding because we all offer different perspectives on the same problem and can honestly find the best possible solution.

- I learned more about teamwork in one week that I have in entire semesters of lab courses.

- You have to be invested in the same goal; you have to work for it to make it work well.

Finally, the following sample of answers were obtained from student in response to the question, "How will this experience help in your discipline?":

- It made me aware of different perspectives. Seeing a problem or challenge from another's point of view is always helpful in any discipline.

- Knowing how to approach and work with people who aren't from the same background as you is a valuable skill in every aspect of life.

- No matter how much we know or study, we cannot tell another person what they want or need. The only way to truly know this is to listen. I imagine using this skill when working with clients to make projects collaborative rather than one sided.

The service-learning component of the Emerging 360 Degree Global Ed Model provides a real-life example of the project planning process, the challenges of working in teams, and the significance of social responsibility. Findings from student reflections showed that those who had participated in previous study-abroad trips had felt like a foreigner in other countries but that in Belize they felt part of the community. One student noted, "We were not visitors, we were accepted into the community, we were part of the culture." Another student wrote, "Leaving the Belizean [school] boys behind at the worksite was sadder than I thought it would be. Some of those boys annoyed me all week, but when our bus pulled out of the gravel lot, I was sad to leave them."

Student reflections also showed that they grew to understand that they are part of a global community and that they can and should make a difference. For example, one student commented, "I learned that social responsibility means that those of us that are fortunate should volunteer our time and resources to help those less fortunate." A second student noted the importance of relationship-building to service work. "I learned that serving is deeper than just sweat and hard work. Connecting with others is the best way to serve and I will continue to do so."

\section{Discussion}

While much remains to be learned, the findings from this study support the ongoing use and study of the Emerging 360 Degree Global Ed Model. Responses to post-trip surveys and open-ended questions demonstrated that students made gains in their understanding of, and ability to relate to and work with, those from a different culture (Belize). Moreover, students expressed their intention to continue learning about different cultures and reported growth in feelings of global social responsibility.

Although not addressed in the design of the study, impacts on the community and university also support continuation of the Emerging 360 Degree Global Ed Model. These impacts include, for example, 
a university that has an ongoing partnership and commitment to our Belizean Peace Village, three years of Healthy Lifestyles Camp at two primary schools, and the completion of several construction projects. Nursing students have assisted with community health clinics, and interested students have toured health facilities and learned about local health and education issues from village partners. Our international Peacework collaborators have partnered with the Belizean government, and as a result community gardens have become a national health priority.

\section{Limitations}

This was a cross-sectional study that relied upon qualitative survey data and rich qualitative data from student journals and self-assessments. Limitations of this study include a small sample size, absence of comparison groups outside of our class, and a non-random sample. The participants were students who self-selected this elective course option. Generally speaking, they may have been more open to international education and global citizenship participation. A further limitation is that data were taken from assignments that were required for the course. It is possible that student responses were skewed by a desire to please the professors (and/or to obtain a better grade), although professors do encourage honest, thoughtful survey and reflection practices. Grading for the survey assignment was full points for completion or 0 points for non-completion. Reflective essays were graded using a rubric.

\section{Conclusions}

Educating the next generation of health-science and STEM professionals requires broad perspectives in the areas of social responsibility and global citizenship. The Emerging 360 Degree Global Ed Model provides a theoretically supported transformative framework of awareness, participation, and responsibility to foster rich student outcomes toward social responsibility and global citizenship. The multi-disciplinary, collaborative nature of international service-learning projects provides an authentic experience in the context of a developing country. The learning that occurs during the teaching and service projects is hands-on and experiential. The mentoring of students is accomplished through faculty guidance and peer-to-peer interaction, and through a community of practice. The pre-trip classroom work serves to prepare the students for the experiences they will have onsite and enables them to work collaboratively. Assessing students through a variety of observational methods, journals, and reflective essays provides insight into the impacts transformational international service-learning trips have on participating college students. Based upon the success of these projects and the lessons learned, the authors are confident that the Emerging 360 Degree Global Ed Model would provide a promising framework for implementing international service-learning courses in other university programs.

\section{Author Note}

Karen R. Breitkreuz, College of Health Sciences, School of Nursing, Boise State University; Tony D. Songer, College of Engineering, Department of Construction Management, Boise State University.

\section{Correspondence}

Correspondence regarding this article should be addressed to Karen R. Breitkreuz, Assistant Professor, School of Nursing, Boise State University, Norco Building, Room 321, 1529 Belmont Street, Boise, ID 83725. Phone: (208) 426-3409. E-mail: karenbreitkreuz@,boisestate.edu

\section{References}

ABET. (2014). Criteria for accrediting engineering programs. Retrieved from 
http://www.abet.org/accreditation/get-accredited-2/get-accredited-step-by-step/

Astin, A. W., Vogelgesan, I. J., Ikeda, E. K., \& Yee, J. A. (2000). How service learning affects students. Los Angeles, CA: University of California, Higher Education Research Institute.

Bergland, M. (2010). What America cares about: Compassion counts more than ever. Retrieved from http://www.parade.com/news/what-america-cares-about/featured/ 100307-compassion-counts-more-than-ever.htm

Bringle, R. G., Hatcher, J. A., \& Jones, S. G. (Eds). (2011). International service learning: Conceptual frameworks and research. Sterling, VA: Stylus Publishing.

Business Roundtable. (2008). America 21: A new approach to the $21^{\text {st }}$ century workforce. Retrieved from http://businessroundtable.org/resources/america-21

Clark, D. R. (2015). Bloom's taxonomy of learning domains. Retrieved from http://www.nwlink.com/ donclark/hrd/bloom.html

Conway, R. (2000). Ethical judgments in genetic engineering: The implications for technology education. International Journal of Technology and Design Education, 10(3), 239-254. doi:10.1023/A:1008964405014

Council on Competitiveness. (2005). Innovate America: Thriving in a world of challenge and change. Retrieved from http://www.compete.org/publications/detail/202/ innovate-america/

Currier, C. L. (2009). Study abroad and nursing. In R. Lewin (Ed.), The handbook of research and practice in study abroad (pp. 133-150). New York, NY: Routledge.

Deardorff, D. K. (2006). Identification and assessment of intercultural competence as a student outcome of internationalization. Journal of Studies in International Education, 10(3), 241-266. doi: $10.1177 / 1028315306287002$

Dewey, J. (1938). Experience and education. New York, NY: Kappa Delta Pi.

Duderstatt, J. (2008). Engineering for a changing world: The millennium project. Ann Arbor, MI: University of Michigan.

Green, M. (2013). Acting as global citizens: A challenge to U.S. colleges and universities. International Educator, 22(6). 52-55. Retrieved from: http://www.nafsa.org/ Find Resources/Publications/Periodicals/International Educator/International Educator Archive $\mathrm{S} /$

Harvan, R. J. (2009). Leadership in interprofessional health education. Sudbury, MA: Jones \& Bartlett.

Helms, R. M, \& Rumbley, L. E. (2012). A primer for global engagement. International Briefs for Higher Education Leaders, 2, 6-7. Retrieved from http://www.acenet.edu/news-room/ Documents/International-Briefs-2012-November-Global-Engagement.pdf

Howe, N., \& Strauss, W. (1991). Generations: A history of America's future, 1584 to 2069. New York, NY: Marrow.

Hudzik, J. (2011). Executive summary: Comprehensive internationalization from concept to action. Retrieved from http://www.nafsa.org//File//cizn2011_execsummary.pdf

Hunter, W. (2004). Knowledge, skills, attitudes, and experiences necessary to become globally competent. (Doctoral dissertation, Lehigh University). Retrieved from http://www.globalcompetence.org/research/WDH-dissertation-2004.pdf

Hunter, W. (2014). About the GCAA. Retrieved from http://www.globallycompetent.com/aboutGCAA/index.htm

Institute of Medicine. (2003). Unequal treatment: Confronting racial and ethnic disparities in health care. Retrieved from http://www.nap.edu/openbook.php?record id=12875\&page=R1

Jonas-Dwyer, D., \& Pospisil, R. (2004, July). The millennial effect: Implications for academic development. Proceedings of the $27^{\text {th }}$ Higher Education Research and Development Society of Australasia Annual Conference, Australia. Retrieved from http://www.herdsa.org.au/wp-content/uploads/conference/2004/papers/jonas-dwyer.pdf

Kolb, D. (1984). Experiential learning: Experience as the source of learning and development. Englewood Cliffs, NJ: Prentice Hall. 
Kuhn, A. (1998). When worlds collide: Engineering students encounter social aspects of production. Science and Engineering Ethics, 4(4). 457-472. doi:10.1007/s11948-998-0039-5

Littleton, M., McMahon, E., \& Wigal, C. M. (2008, October). Measuring the benefit of service oriented student design projects. Proceedings of the $38^{\text {th }}$ Annual Frontiers in Education Conference, Sarasota Springs, FL. doi:10.1109/FIE.2008.4720361

Looper, L. (2011). How Generation Z works. Retrieved from http://people.howstuffworks.com/culture-traditions/generation-gaps/generation-z1.htm

Martin, M. (2007). The millennial student: A new generation of learners. Athletic Training Education Journal, 2(2), 42-46.

Mbugua, T. (2010). Fostering culturally relevant/responsive pedagogy and global awareness through the integration of international service-learning in courses. Journal of Pedagogy, 1(2), 87-98. doi: 10.2478/v10159-010-0011-8

National Academy of Engineers. (2004). The engineer of 2020: Visions of engineering in the new century. Washington, DC: National Academies Press.

Northern Illinois University. (2011). Millennial's: Our newest generation in higher-education. Retrieved from http://www.facdev.niu.edu/facdev/resources/guide/students/ millennials our newest generation in higher education.pdf

Oxfam Development Education Programme. (2006). Education for global citizenship: A guide for schools 2006. Retrieved from: http://www.oxfam.org.uk/ /media/Files/Education/ Global\%20Citizenship/education for global citizenship a guide for schools.ashx

Partnership for 21st Century Skills. (2012). Learning for the 21st century: A report and MILE guide for 21 st century skills. Retrieved from: http://eric.ed.gov/?id=ED480035

Pelligrino, J. H. (2012). Education for life and work: Developing transferable knowledge and skills in the 21 st century. Retrieved from http://www.nap.edu/catalog/13398/ education-for-life-and-work-developing-transferable-knowledge-and-skills

Piaget, J. (1952). The origins of intelligence in children. New York, NY: International University Press.

Posnick-Goodwin, S. (2010). The most technically advanced yet. Educator, 14(5). Retrieved from https://www.cta.org/en/Professional-Development/Publications/ 2010/02/Educator-Feb-10/Most-technologically-advanced-generation.aspx

Renfro, A. (2012, December 5). Meet Generation Z [Blog Post]. Retrieved from http://gettingsmart.com/2012/12/meet-generation-Z/

Ruddock, H., \& Turner, D. S. (2007). Developing cultural sensitivity: Nursing student's experiences of a study abroad programme. Journal of Advanced Nursing, 59(4), 361-369. doi:10.111/j.1365-2648-2007-04312.x

Schattle, H. (2008). The practices of global citizenship. Lanham, MD: Rowman \& Littlefield.

Songer, A. D., \& Breitkreuz, K. R. (2014). Collaborative international service learning: Developing engineering students as global citizens. International Journal for Service Learning in Engineering, 9(2). Retrieved from http://library.queensu.ca/ojs/index.php/ijsle/article/view/5621

Sununu, J. C. (2013, June 12). STEM fund key to U.S. global competitiveness [Blog Post]. Retrieved from http://thehill.com/blogs/congress-blog/education/ 305061-stem-fund-key-to-us-global-competitiveness

Sutton, R. C., \& Rubin, D. L. (2010). Documenting the academic impact of study abroad: Final report of the GLOSSARI Project, 2010. Retrieved from http://glossari.uga.edu/datasets/pdfs/FINAL.pdf

United Nations. (2014). Millennium development goals. Retrieved from http://www.un.org/millenniumgoals/ 